\title{
Evaluation of original Roundup $₫$ effects on Biomphalaria glabrata (Say, 1818)
}

\author{
Marta Julia Faro ${ }^{1 *}$ \\ Vanessa Silva Moura ${ }^{1}$ \\ Ronaldo Carvalho Augusto ${ }^{2}$ \\ Maurício Carvalho de Vasconcellos ${ }^{2}$ \\ Instituto Oswaldo Cruz, Fiocruz \\ ${ }^{1}$ Laboratório de Biologia Parasitologia de Mamíferos Silvestres Reservatórios \\ ${ }^{2}$ Laboratório de Avaliação e Promoção da Saúde Ambiental \\ Avenida Brasil, 4365, Pavilhão Lauro Tavassos, Anexo1, CEP 21.040-30 Rio de Janeiro - RJ, Brazil \\ * Autor para correspondência \\ mjfaro@ioc.fiocruz.br
}

Submetido em 23/09/2020

Aceito para publicação em 10/02/2021

\section{Resumo}

Avaliação do efeito do Roundup ${ }^{\circledR}$ original em Biomphalaria glabrata. O presente estudo teve como objetivo avaliar a ação do Roundup ${ }^{\circledR}$ original sobre o molusco Biomphalaria glabrata, infectado e não infectado por Schistosoma mansoni, observando a mortalidade e a biologia reprodutiva. Os caramujos foram submetidos às concentrações aquosas: 0,$1 ; 0,09 ; 0,08 ; 0,07 ; 0,06 ; 0,05 ; 0,04 ; 0,03 ; 0,02,0,018 ; 0,016 ; 0,014 ; 0,012$ e 0,01 (\%) do Roundup Original ${ }^{\circledR}$ para a determinação da CL50 sendo essa concentração testada durante 30 dias sobre os moluscos. Para a observação da atividade reprodutiva frente à exposição ao agrotóxico, quatro grupos de B.glabrata foram formados: infectados e expostos ao agrotóxicos, infectados e não expostos (controle), não infectados e expostos e não infectados e não expostos (controle). $\mathrm{A} \mathrm{CL}_{50}(0,012 \%$ da solução aquosa do Roundup original) apresentou mortalidade que não ultrapassou 95\%, 24, 48 e 72 h de exposição durante os 30 dias e perdendo totalmente o efeito após o $27^{\circ}$ dia de teste. A atividade reprodutiva de caramujos não infectados e expostos foi de $30,3 \pm 20,5$ ovos em 2,7 $\pm 1,2$ massas ovígeras, sendo observada redução de $51 \%$ na média de moluscos eclodidos $(11,5 \pm 7,5)$ em comparação ao grupo controle $(23,9 \pm 18,0)$ ao longo de quatro semanas $(\mathrm{p}=0,003)$. Os resultados indicam que a concentração letal (CL50) da solução aquosa $0,012 \%$ do Roundup Original tem ação significativa sobre B. glabrata durante 27 dias. O Roundup diminui significativamente a fertilidade dos moluscos infectados e expostos em comparação com o grupo controle.

Palavras-chave: Agrotóxico; Molusco

\section{Abstract}

The objective of this work is to evaluate the action of original Roundup ${ }^{\circledR}$ on the snail Biomphalaria glabrata infected and not infected by Schistosoma mansoni by observing its mortality and reproductive biology. Snails were submitted for 30 days to aqueous solutions of original Roundup at concentrations of $0.1,0.09$, $0.08,0.07,0.06,0.05,0.04,0.03,0.02,0.018,0.016,0.014,0.012$ and $0.01(\%)$ to determine $\mathrm{LC}_{50}$. To analyze 
the reproductive activity of $B$. glabrata, against the pesticide, four $B$. glabrata groups were formed: infected and exposed to the pesticide; infected and not exposed (control); not infected and exposed; and not infected and not exposed(control). $\mathrm{LC}_{50}(0.012 \%$ aqueous solution of original Roundup) caused mortality of at most up to $95 \%$ for 24,48 and $72 \mathrm{~h}$ during the experimental period (30 days), and lost effect totally after 27 days. The reproductive activity of the non-infected and exposed snails was $30.3 \pm 20.5$ eggs in $2.7 \pm 1.2$ egg masses, and there was a reduction of $51 \%$ in the average number of hatched snails $(11.5 \pm 7.5)$ in comparison to the control group $(23.9 \pm 18.0)$ for four weeks $(\mathrm{p}=0.003)$. The results indicate that the lethal concentration (LC50) of the $0.012 \%$ aqueous solution of original Roundup has a significant action on Biomphalaria glabrata for up to 27 days. Roundup significantly diminished the fertility of infected and exposed snails in comparison with the control group.

Key words: Herbicide; Snail

\section{Introduction}

Pesticides are chemical agents that have a series of harmful effects on human health and environmental quality. The widespread use of agrochemicals on crops and livestock has led to deleterious effects on the environment, by contaminating living things and accumulating in ecosystems (biota, water, air, soil, sediments) (PERES; MOREIRA, 2007). Herbicides and insecticides have the potential to cause dramatic changes in natural communities of macroinvertebrates, plankton and fish (RELYEA, 2005). Snails are ubiquitous members of aquatic communities and have multiple roles in ecosystems. They are primary consumers and decomposers; and serve as a major food source for a variety of vertebrate and invertebrate predators (GUSTAFSON et al., 2015). Snails are also obligate first intermediate hosts of trematodes that cause diseases in humans, livestock and wildlife (TOLEDO; FRIED, 2011). Given the importance of snails in nutrient cycling, food webs and parasite transmission, along with their developing role in the field of ecotoxicology (RITTSCHOF; MCCLELLAN-GREEN, 2005), it is important to understand the impacts pesticides have on snails.

Original Roundup, whose active ingredient is glyphosate (N-(phosphonomethyl)glycine), is an agrochemical belonging to the organophosphate group (ALMEIDA, 2014). Its formula is composed of $480 \mathrm{~g} / \mathrm{L}(48.0 \% \mathrm{~m} / \mathrm{v})$ of isopropylamine salt of $\mathrm{N}$-(phosphonomethyl)glycine; $360 \mathrm{~g} / \mathrm{L}(36.0 \% \mathrm{~m} / \mathrm{v})$ of equivalent acid of $\mathrm{N}$-(phosphonomethyl)glycine (glyphosate); and $684 \mathrm{~g} / \mathrm{L}(68.4 \% \mathrm{~m} / \mathrm{v})$ inert ingredients.
Roundup is used in more than 130 countries, mainly for weed control before planting, including Brazil, where it is registered with the Ministry of Agriculture (MONSANTO, 2018).

Biomphalaria is a genus of freshwater snails of the family Planorbidae. The species B. glabrata (Say, 1818) has great epidemiological importance because it can be naturally infected by the trematode Schistosoma mansoni (Sambon, 1907) (CARVALHO et al., 2008). Even though Biomphalaria species can be found in various lotic and lentic environments, artificial channels offer the most suitable habitat for these vector species (LEITE et al., 2016), due to organic matter accumulation and the micro-habitats provided.

Bionomic parameters of snails, such as reproduction and survival, can be substantially altered by environmental conditions. The presence of pesticides in the biotopes inhabited by snails can have direct action on their reproductive biology (GUSTAFSON et al., 2015) as well as a significant impact on the dynamics of the parasite-host relationship (KOPRIVNIKAR; WALKER, 2011). In a review article, Monte and Maldonado-Júnior (2017) discussed the interface between pesticides and helminths. According to them, new strategies to minimize the toxic action mechanism of these chemicals should be conducted to better understand the action of pesticides on the transmission dynamics of the biological cycle of these parasites. Besides this, the development of infection in the vertebrate or invertebrate host is the result of a balance between the host and pathogen, due to external factors such as pollutants and/or internal factors like host susceptibility (MOHAMED, 2011). 
Several studies have reported reduced fecundity of snails when faced with stress, such as infection and exposure to molluscicides and herbicides (MELLO-SILVA et al., 2007; KOPRIVNIKAR; WALKER, 2011; FARO et al., 2013). Because Roundup is widely used in Brazil, and its residues pollute many water courses that serve as habitat for snails of the genus Biomphalaria that are intermediate hosts of S.mansoni, the objective of this study was to evaluate the duration of the effect of the original herbicide Roundup and the reproductive biology of snails infected and not infected by S. mansoni.

\section{Materials and Methods}

\section{Maintenance of the Schistosoma mansoni biological cycle in the laboratory}

The snails were kept in the Laboratory for Biology and Parasitology of Wild Mammal Reservoirs at the Oswaldo Cruz Institute (Fiocruz) in Rio de Janeiro between 2015 and 2016 and descended from specimens collected in the municipality of Sumidouro in the state of Rio de Janeiro, Brazil (22 $02^{\circ} 46^{\prime \prime}$ S and 42 41'42”W), a rural area with Atlantic Forest fragments. They were kept in 2-Liter glass aquariums with chlorine-free water at $25 \pm 1{ }^{\circ} \mathrm{C}$, on a layer of clay mixed with calcium carbonate (10:1).

The snails were identified at the species level (BRASIL, 2008). They were fed ad libitum with fresh lettuce leaves according to Paraense and Corrêa (1989). The S. mansoni strain (SU) was obtained from a fecal sample from Nectomys squamipes (water rat) in Sumidouro. In this city, $N$. squamipes is the main nonhuman host of S. mansoni (COSTA-SILVA et al., 2012). This $S$. mansoni strain (SU) is maintained in the same laboratory by passage in mice (FERNANDEZ, 1997). The procedures for collecting the feces of infected mice and for later individual exposure of the snails $(n=40)$ to 10 miracidia were the same as described by Paraense and Corrêa (1989). Thirty days after infection, the snails stored in chlorine-free water were individually exposed to light (60-watt incandescent bulb for $4 \mathrm{~h}$ ) to verify the release of cercariae. To count the cercariae, three aliquots
( $0.5 \mathrm{~mL}$ of water with cercariae) were distributed in glass dishes with lugol and counted with the aid of a stereoscopic microscope (AUGUSTO et al., 2015).

This study was approved by the Oswaldo Cruz Foundation Ethics Committee on Animal Use (CEUA number L-023/2015, approved on June 18, 2015).

\section{Preparation of the aqueous solutions of original Roundup}

The concentrations used in the bioassays were prepared from original Roundup in successive dilutions in type 2 water. A stock solution was prepared with 1.0 $\mathrm{mL}$ of original Roundup completed to $1,000 \mathrm{~mL}$ with type 2 water in a round-bottom volumetric flask, to obtain a concentration $0.1 \%$ (360 mg/L of glyphosate).

Successive aqueous dilutions were obtained from the stock solution $(0.1 \%)$, with concentrations of 0.09 , $0.08,0.07,0.06,0.05,0.04,0.03,0.02,0.018,0.016$, $0.014,0.012$ and $0.01(\%)$ in a final volume of $1,000 \mathrm{~mL}$ of each solution to obtain the $\mathrm{LC}_{50}$. These were divided into two equal portions of $500 \mathrm{~mL}$. For each battery of tests, a control group was submitted to pure type 2 water in the same volume as the solutions.

After preparation of the dilutions of original Roundup, the temperature of the solutions and room temperature were measured.

\section{Biosassays to determine the lethal concentration ( $\left.\mathrm{LC}_{50}\right)$}

The bioassays to ascertain 50\% lethal concentration $\left(\mathrm{LC}_{50}\right)$ were performed according to the method described by Vasconcellos and Amorim (2003), developed to investigate possible variations of the molluscicidal effect of a candidate product on snails.

\section{Exposure period}

Twenty adult (sexually mature) specimens of $B$. glabrata with shell diameter between 8 and $10 \mathrm{~mm}$ were exposed to each concentration in two $1,000 \mathrm{~mL}$ flasks (experiment and replication), with 10 animals in each flask containing $500 \mathrm{~mL}$ of the solution, during $24 \mathrm{~h}$ (exposure period). The flasks were covered with plastic 
screens to allow entry of air and prevent the snails from escaping. The space between the screen and solution allowed the snails to exit from the solution without leaving the flask. In this period, the flasks were kept at room temperature, and the animals did not receive food.

\section{Recovery period}

After the exposure period ( $24 \mathrm{~h}$ after the start of the bioassays), both the snails that had moved out of the solution and those that remained in it were retrieved from the flasks and rinsed with distilled water to remove the residual solution on the shell. The dead snails were counted to determine the mortality rate. The animals that had moved out of the solution were separated in glass cups containing $50 \mathrm{~mL}$ of type 2 water, and the surviving snails that had remained in the solution were transferred to cups containing the diluent (type 2 water) in the same initial volume, for a further period of $24 \mathrm{~h}$ (recovery period). They were fed with small pieces of fresh lettuce.

\section{Characterization of the dead snails}

After the recovery period ( $48 \mathrm{~h}$ after the start of the bioassays), the dead and surviving animals were counted again with the aid of a stereoscopic microscope. The snails that died during the tests were distinguished by alteration of shell color and absence of muscular contractions. Generally, the cephalopedal mass was characteristically distended as well.

\section{Evaluation of the duration of the action of Roundup}

To determine the duration of original Roundup's action on the Biomphalaria glabrata specimens, these were observed for 30 days. This test was conducted in a room with controlled temperature and relative humidity, protected against direct sunlight.

On the first day of the test, $40 \mathrm{~L}$ of the original Roundup solution was prepared at $\mathrm{LC}_{50}(0.012 \%)$ from an aqueous stock solution (type 2 water) with initial concentration of $0.1 \%(360 \mathrm{mg} / \mathrm{L})$. This solution was stored in clear plastic bottles and maintained at room temperature during the entire testing period. The control substance (40 L of type 2 water) was maintained under the same conditions.

Every day, 20 snails with shell diameter between 8 and $10 \mathrm{~mm}$ were exposed to original Roundup at a concentration of $0.012 \%$. They were then divided into two groups of 10 snails each and placed in two $1,000 \mathrm{~mL}$ flasks containing $500 \mathrm{~mL}$ of the solution. In the control group, two groups of 10 snails were also placed in two flasks of the same size and with the same volume of type 2 water. This procedure was repeated for 30 days, during which the alteration of the product's action was monitored daily. A total of 600 snails were used for this experiment.

The snails were also observed daily to detect the mortality of the animals of each group exposed to the solution after 24, 48 and $72 \mathrm{~h}$, a procedure that was performed for 30 days. The observations were performed without handling the snails, where the dead animals were counted, removed from the flasks with the solution and discarded, while the living snails remained under observation. The same procedure was carried out with the control animals. The room temperature and solution temperature were read daily, along with relative air humidity.

\section{Reproductive parameters}

In the Laboratory for Biology and Parasitology of Wild Mammal Reservoirs at the Oswaldo Cruz Institute (Fiocruz) in Rio de Janeiro, adult snails at 90 days and sexual maturity (approximately $8-10 \mathrm{~mm}$ shell diameter) were kept for breeding. Theses snails were maintained in 6 plastic aquariums with 4L and 25 individuals per aquarium (150 snails in total) with a layer of clay mixed with calcium carbonate (10: 1) according to Paraense and Corrêa (1989) and dechlorinated water, which was changed every 15 days. Water temperature was maintained at $25 \pm 1{ }^{\circ} \mathrm{C}$. The snails were fed ad libitum with fresh lettuce leaves. After this time, 20 snails that were eliminating cercariae were separated.

These, these 20 snails were then separated into two groups: Infected/not exposed - 10 snails (control); Infected/exposed to herbicide - 10 snails. Next, more 
than 20 snails were separated. These 20 snails were divided into two groups: Not infected/not exposed - 10 snails (control); Not infected/exposed to herbicide - 10 snails. All snails were kept in $200 \mathrm{~mL}$ individual glass aquariums.

The snails were exposed for $24 \mathrm{~h}$ to $100 \mathrm{~mL}$ of Roundup at the concentration of $0.012 \%$ in glass flasks with a volume of $200 \mathrm{~mL}$.

These snails were observed for eight weeks to ascertain the fecundity (number of egg masses per snail and number of eggs per mass) and fertility (number of eggs hatched per snail), as defined by Faro et al. (2013). The reproductive biology results were expressed as mean and standard deviation and submitted to the nonparametric Kruskal-Wallis test followed by the Dunn post-hoc test $(\alpha=5 \%)$. All the analyses were conducted with the GraphPadPrism software (GraphPad V.4.00, GraphPad vol. 3.02, Prism Inc.). The 50\% lethal concentration value $\left(\mathrm{LC}_{50}\right)$ was calculated using the Análise Probita program (FINNEY, 1971), which includes the chi-squared test $\left(\mathrm{X}^{2}\right)$. The values of the mortality curve were determined by the arithmetic mean and expressed as percentage.

\section{Results}

The $\mathrm{LC}_{50}$ value was $0.012 \%(43.2 \mathrm{mg} / \mathrm{L}$ of glyphosate), and no significant difference in the molluscicidal effect among the concentrations evaluated was observed $\left(X^{2}=22.36 ; D F=13 ; p>0.05\right)$.

The results revealed that the mortality of the snails, computed 24,48 and $72 \mathrm{~h}$ after exposure to original Roundup, was on average $95 \%$ up to the fifth day after preparing the solution, with an abrupt decline in mortality on the seventh day, when it was zero. After the eighth day of observation, the mortality started increasing and fluctuating for 24,48 and $72 \mathrm{~h}$, but did not exceed $95 \%$ until the $27^{\text {th }}$ day, when no more deaths were observed in the first $24 \mathrm{~h}$.

In the control group there was no mortality until the sixth day, and low mortality was observed until the $21^{\text {st }}$ day after the start of the test, when the mortality did not exceed $20 \%$ (Figure 1).

The average temperatures of the solution of original Roundup and the testing ambient during the $\mathbf{3 0}$ days are presented in the figure below. There was a similarity in the curves throughout the experiment, with average room temperature of $26.8^{\circ} \mathrm{C}$ and solution temperature of $25.6^{\circ} \mathrm{C}$ (Figure 2).

FIGURE 1: Mortality (\%) of Biomphalaria glabrata after 24, 48 and $72 \mathrm{~h}$ of exposure to an aqueous solution of original Roundup at concentration of $0.1 \%$ (360 $\mathrm{mg} / \mathrm{L}$ of glyphosate $=1,000 \mathrm{ppm})$, for 30 days.

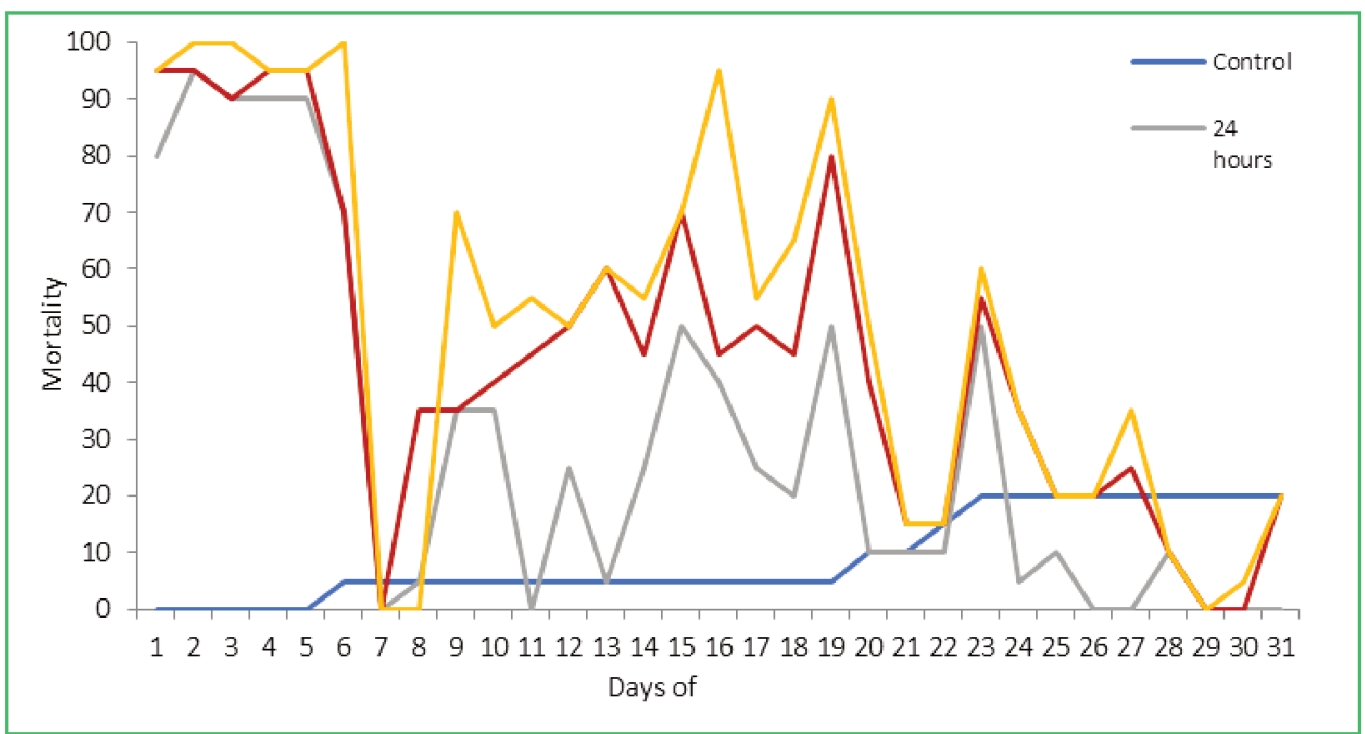


FIGURE 2: Average temperature $\left({ }^{\circ} \mathrm{C}\right)$ of the aqueous solution of original Roundup at concentration of $0.1 \%(360 \mathrm{mg} / \mathrm{L}$ of glyphosate $=$ $1,000 \mathrm{ppm}$ ) and room temperature during 34 days of mortality observation of Biomphalaria glabrata.

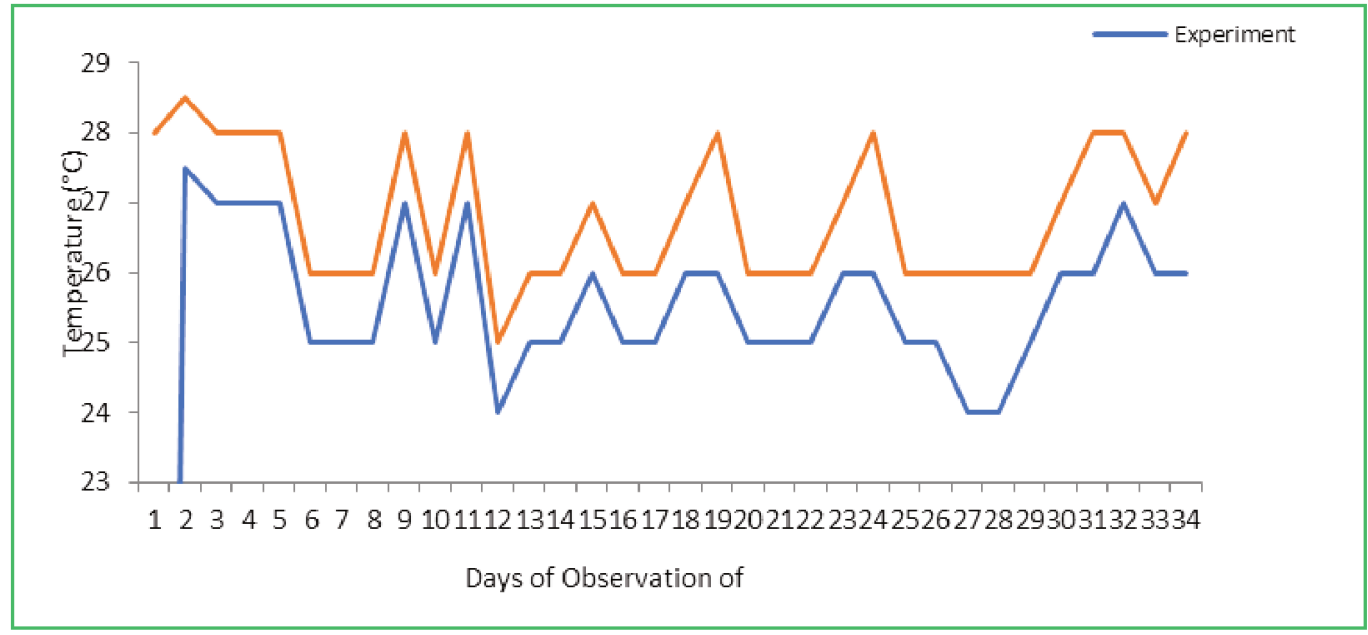

During the four weeks, an average of $41.8 \pm 31.5$ eggs in $3.7 \pm 1.9$ egg masses per snail were produced by the group that was not infected and not exposed to glyphosate (control), with hatching of $23.9 \pm 18.0$ snail in the period. The exposure of the non-infected snails to glyphosate significantly altered all the reproductive parameters considered in this study. The reproductive activity of the infected and exposed snails was $30.3 \pm$ $20.5 \mathrm{eggs}$ in $2.7 \pm 1.2 \mathrm{egg}$ masses, with a reduction of $51 \%$ in the average number of hatched snails (11.5 \pm $7.5)$ in comparison with the control group (23.9 \pm 18.0$)$ during the four weeks $(\mathrm{p}=0.003)$ (Table 1)

The infection by $S$. mansoni caused significant negative effects on the average production of egg masses, eggs laid, snails hatched, fertile eggs and infertile eggs in comparison to the group not infected and exposed to glyphosate and/or the control group $(p<0.0001)$. The reproductive activities of the infected snails declined to critical levels, where they produced an average of $0.2 \pm 0.2$ eggs in $0.04 \pm 0.05$ egg masses, without the hatching of any eggs during the four weeks. Likewise, the association of infection by $S$. mansoni and exposure to glyphosate significantly reduced the reproductive activity of the snails in comparison with the control group $(\mathrm{p}<0.0001)$. Infected and exposed snails produced an average of $9.0 \pm 6.4$ eggs in $0.4 \pm 0.1$ egg masses, with $0.65 \pm 0.6$ snails hatched during the four weeks.

TABLE 1: Effect of exposure to glyphosate (Roundup) on the reproductive biology of Biomphalaria glabrata infected by Schistosoma mansoni observed during four weeks after exposure.

\begin{tabular}{lccccc}
\hline & $\begin{array}{c}\text { Egg masses/ } \\
\text { snail }\end{array}$ & Eggs/snail & $\begin{array}{c}\text { Hatched } \\
\text { snails }\end{array}$ & Fertile eggs & Infertile eggs \\
\hline Not infected/not exposed (control) & $3.7 \pm 1.9^{\mathrm{a}}$ & $41.8 \pm 31.5^{\mathrm{a}}$ & $23.9 \pm 18.0^{\mathrm{a}}$ & $39.4 \pm 29.5^{\mathrm{a}}$ & $2.4 \pm 2.2^{\mathrm{a}}$ \\
Not infected/exposed & $2.7 \pm 1.2^{\mathrm{a}}$ & $30.3 \pm 20.5^{\mathrm{a}}$ & $11.5 \pm 7.5^{\mathrm{b}}$ & $28.2 \pm 19.2^{\mathrm{a}}$ & $2.1 \pm 1.5^{\mathrm{a}}$ \\
Infected/not exposed & $0.04 \pm 0.05^{\mathrm{b} . \mathrm{c}}$ & $0.2 \pm 0.2^{\mathrm{b} . \mathrm{c}}$ & $-^{\mathrm{c} .}$ & $0.2 \pm 0.2^{\mathrm{b} . \mathrm{c}}$ & $-^{\mathrm{b} . \mathrm{c}}$ \\
Infected/exposed & $0.4 \pm 0.1^{\mathrm{c}}$ & $9.0 \pm 6.4^{\mathrm{c}}$ & $0.65 \pm 0.6^{\mathrm{a}}$ & $8.8 \pm 6.2^{\mathrm{c}}$ & $0.2 \pm 0.2^{\mathrm{c}}$ \\
\hline
\end{tabular}

$\mathrm{a}, \mathrm{b}, \mathrm{c}=$ Different letters indicate statistically significant differences between the groups at $5 \%$. Data are mean \pm standard deviation per snail. Conventional sign used: - Number equal to zero not resulting from rounding. 


\section{Discussion}

In evaluating the duration of the effect of the aqueous solution of original Roundup at the $50 \%$ lethal concentration $\left(\mathrm{LC}_{50}\right)$ of $0.012 \%(43.2 \mathrm{mg} / \mathrm{L}$ of glyphosate) on Biomphalaria glabrata for 30 days, we observed continued full effect of the product in the first five days, with $95 \%$ mortality, after which there was an abrupt decline in mortality, which reached zero, and then increased again before losing potency from the $27^{\text {th }}$ day onward. That sharp decline in the mortality on the $5^{\text {th }}$ day suggests a molecular rearrangement of the product when exposed to the environment, and the decline of this activity as of the $27^{\text {th }}$ day might have been caused by the prolonged exposure of the solution to light, which can accelerate the degradation of the active ingredient. This was reported by Gillet and Bruaux (1961) regarding niclosamide, which lost nearly $80 \%$ of its molluscicidal potency on $B$. glabrata after being exposed to ultraviolet light for $24 \mathrm{~h}$.

With respect to the continued action of a product with molluscicidal action, it is important to stress that the activity of these products should last long enough to obtain the desired effect; but should not persist much longer than this period in the places where it is applied. This is one of the main advantages of using biodegradable pest control products, because they do not accumulate in the environment and/or remain active for long periods. On the other hand, this may require repeated applications.

Gustafson et al. (2015) evaluated the effect to atrazine on four snail species (Biomphalaria glabrata, Helisoma trivolvis, Physa acuta and Stagnicola elodes) in an acute test for $48 \mathrm{~h}$ at a concentration of $1,000 \mu \mathrm{g} / \mathrm{L}$ and in a chronic test for 28 days at concentrations varying from 0.3 to $30 \mu \mathrm{g} / \mathrm{L}$. They observed that the survival was high, with an average above $90 \%$ for the four species, and there was no significant action of the product after four weeks of testing. The species that had the highest survival was $P$. acuta, with $94.1 \%$, while B. glabrata had the lowest survival, with $61.5 \%$. In the present study, we observed very low survival in the first five days of exposure to original Roundup, but this survival increased as the experiment progressed, so that after 30 days the survival was about $80 \%$. This suggests the product lost effect due to degradation.

Prosser et al. (2016), in a pioneer study, tested the action of the nonionic surfactant polyoxyethylene tallow amine (POEA) MON 0818, present in various herbicides with formulations containing glyphosate, on the oviposition, egg viability and mortality of juvenile and adult specimens of the freshwater snail Planorbella pilsbryi, which is important in the food chain of aquatic invertebrates and fish in North America. The $\mathrm{LC}_{50}$ for adult snails was $9.1 \mathrm{mg} / \mathrm{L}$ and $4.0 \mathrm{mg} / \mathrm{L}$ for the young ones, indicating their greater sensitivity. However, the concentration of $9.1 \mathrm{mg} / \mathrm{L}$ did not have an effect on egg viability. Furthermore, oviposition was inhibited at the concentration of $2.0 \mathrm{mg} / \mathrm{L}$, but returned to normal when the snails were relocated to clean water. The concentration of $2.7 \mathrm{mg} / \mathrm{L}$ caused alterations in the tentacles of the adult snails. Mortality was lower for the adult than the juvenile snails, for which complete mortality occurred at a concentration of $21.4 \mathrm{mg} / \mathrm{L}$. In the present study, the mortality was high for the adult snails exposed to the concentration of $0.012 \%(360 \mathrm{mg} / \mathrm{L}$ of glyphosate) of the integral formulation of original Roundup, which contains this same surfactant. This suggests that the surfactant present in the formula was not responsible for the direct action causing the mortality of the snails.

The data obtained for the reproductive biology show that Roundup, at the dose applied, was not significantly toxic to the non-infected and exposed snails. However, for the infected snails, the existence of the infection itself was a stronger stress factor than exposure to the herbicide. Gustafson et al. (2015) observed that relevant concentrations of atrazine in the environment can indirectly affect the reproduction, survival, abundance and biomass, affecting the consumption reserve or the parasite-host relationship. The same researchers tested the effect of atrazine on the snails' reproduction and did not observe significant effects on Biomphalaria glabrata, while for Stagnicola elodes the egg production was drastically reduced. (OLIVEIRA-FILHO et al., 2009) tested the insecticide endosulfan on Biomphalaria tenagophila at non-acute and lethal concentrations for two generations. The results 
showed a significant inhibition or delay in the reduction of fecundity (F1 individuals) at the concentration of 0.1 $\mathrm{mg} / \mathrm{L}$ in relation to the control group. When the snails only infected by $S$. mansoni laid eggs, they did not hatch during the entire experimental period (Table 1). Faro et al. (2013) also observed a reduction in the fecundity and fertility of B. glabrata infected by S. mansoni and called that phenomenon parasitic castration. Although the infected and exposed snails laid eggs, the hatching rate was greatly reduced, to $0.65 \pm 0.6$ compared to the control group, with $23.9 \pm 18.0$, suggesting that infection and exposure to the herbicide interacted to affect the snails' reproductive biology by interfering in embryo development. Ghaffar-Abdel et al. (2016) investigated the effects of three commercial herbicides (butralin, glyphosate and pendimethalin) on Biomphalaria alexandrina. The sublethal concentrations of all three compounds reduced the growth rate, egg hatching rate, egg masses and eggs per snail. The authors attributed the reduced fecundity to the deterioration of the activities of the enzymes aspartate aminotransferase and alanine aminotransferase in the snails' tissues and hemolymph, causing damage to the cells and altering physiological activities, resulting in reduction or elimination of oviposition.

Geraldino (2004) and Cantina (2012) demonstrated that $B$. glabrata, besides being an intermediate host of $S$. mansoni, is an excellent bioindicator of aquatic habitats since this species is sensitive to the action of chemical and physical agents. In the present study, we evaluated the molluscicidal action of original Roundup on these snails to observe its secondary effects (not mainly as a molluscicide), since after each application of the product on crops, the excess or residue can be carried by rainwater to water collections where snails live, affecting them. We also investigated the variation in the effects of the herbicide according to the time lapse after application, to ascertain the negative effects on the environment (e.g., pollution from runoff and improper disposal of packaging, toxicity in freshwater habitats) and human health (inadequate management during application by farm workers).

The concentration tested by us was $0.012 \%$ of the integral product while the concentration recommended by Monsanto (2018) for application on crops is $1.25 \%$ (1 to $5 \mathrm{~L}$ of the product to 80 to $400 \mathrm{~L}$ of water per hectare); our concentration was less than one-tenth of the recommended dose. Despite this difference, we observed all the biosecurity measures for handling and use of the product.

The results indicate that the exposure of Biomphalaria glabrata to the $\mathrm{LC}_{50}$ of the aqueous solution of original Roundup causes average mortality of $95 \%$ during the first five days, which declines until the $27^{\text {th }}$ day, hence significantly diminishing the fertility of the infected and exposed snails in comparison with the control group. Therefore, the transmission of $S$. mansoni can be strongly affected by exposure to the herbicide, having a significant impact on the dynamics of the parasite-host relationship.

\section{References}

ALMEIDA, P. R. Toxidade aguda (LC50) e efeitos comportamentais e toxicológicos do formulado comercial Roundup original ${ }^{\circledR}$ em girinos de Physaleumus curvieri (Anura leptodactilidae) e Rhinella icterica (Anura; Bufonidae). 2014.95 f. Dissertação (Mestrado em Ciência e Engenharia Ambiental) Universidade Federal de Alfenas, Poços de Caldas. 2014.

AUGUSTO, R. C.; FRIANI, G. V.; VASCONCELlOS, M. C.; RODRIGUES, M. L. A.; MELLO-SILVA, C. C. Schistosoma mansoni: phytochemical effect on aquatic life cycle. Open Journal Veterinary Medicine, Taipei, v. 5, p. 127-132, 2015.

BRASIL. Vigilância e controle de moluscos de importância epidemiológica: diretrizes técnicas. 2. ed. Brasília: Ministério da Saúde, 2008. 178 p.

CANTINA, R. S. Estudo da resposta do caramujo Biomphalaria glabrata (Say, 1818) frente a estímulos ambientais estressores, com enfoque na proteína HSP70. 2012. 156 f. Tese (Doutorado em Tecnologia Nuclear - Aplicações) - Universidade de São Paulo, São Paulo. 2012.

CARVALHO, O. S.; COELHO, P. M. Z.; LENZI, H. L. Schistosoma mansoni \& esquistossomose: uma visão multidisciplinar. Rio de Janeiro: Editora Fiocruz, 2008. 1124 p.

COSTA-SILVA, M.; ANDRADE, B. L.; GARCIA, J. S.; NEVES, R. H.; RODRIGUES-SILVA, R.; MACHADO-SILVA, J. R.; MALDONADO-JUNIOR, A. Susceptibility of a Brazilian wild rodent isolate of Schistosoma mansoni to praziquantel in mice. Experimental Parasitology, Amsterdam, v. 130, p. 394-399, 2012.

FARO, M. J.; PERAZZINI, M.; CÔRREA, L. R.; MELLO-SILVA, C. C.; PINHEIRO, J.; MOTA, E. M.; SOUZA, S.; ANDRADE, Z.; MALDONADO, A. J. Biological, biochemical and histopathological features related to parasitic castration of Biomphalaria glabrata infected by Schistosoma mansoni. Experimental Parasitology, Amsterdam, v. 134, p. 228-234, 2013. 
FERNANDEZ, M. A. Schistosoma mansoni infections in the three months of life of sympatric intermediate host Brazil. Memórias do Instituto Oswaldo Cruz, Rio de Janeiro, v. 92, n. 1, p. 27-29, 1997. FINNEY, D. J. Probit analysis. 3. ed. New Delhi: Cambridge University Press, 1971. 333 p.

GERALDINO, B. R. Estudo dos efeitos embriotóxicos de xenobióticos em Biomphalaria glabrata. 2004. 92 f. Dissertação (Mestrado em Saúde Pública) - Escola Nacional de Saúde Pública Sérgio Arouca, Rio de Janeiro. 2004.

GHAFFAR-ABDEL, F.; AHMED, A. K.; BAKRY, F.; RABEI, I.; IBRAHIM, A. The impact of three herbicides on biological and histologal aspects of Biomphalaria alexandrina, intermediate host of Schistosoma mansoni. Malacologia, Ann Arbor, v. 59, n. 2, p. 197-210, 2016.

GILLET, J.; BRUAUX, P. Essais en laboratoire des nouveaux molluscicides Bayer 73 et ICI 24223. Bulletin World Health Organization, Geneva, v. 25, p. 509-517, 1961.

GUSTAFSON, K. D.; BELDEN, J. B.; BOLEK, M. G. The effects of the herbicide atrazine on freshwater snails. Ecotoxicology, Knoxville, v. 24, p. 1183-1197, 2015.

KOPRIVNIKAR, J.; WALKER, P. A. Effects of the herbicide atrazine's metabolites on host snail mortality and production of trematode cercariae. Journal of Parasitology, Lawrence, v. 95, n. 5 , p. 823-827, 2011.

LEITE, M. G. P.; PIMENTA, E. C.: FUJACO, M.A. G.: ESKINAZISANT, A. Irrigation canais in Melo creek basin (Rio Espera and Capaela Nova municipals, Minas Gerais, Brazil): habitats to Biomphalaria (Gastropoda:Planorbidae) and potencial spread of schistosomiasis. Brazilian Journal of Biology, São Carlos, v. 76, n. 3, p. 638-644, 2016.

MELLO-SILVA, C. C.; VILAR, M. M.; BEZERRA, J. C. B.; VASCONCELLOS, M. C.; PINHEIRO, J.; RODRIGUES, M. L. Reproductive activity alterations on the Biomphalaria glabrata exposed to Euphorbia splendes var. histopii latex. Memórias do Instituto Oswaldo Cruz, Rio de Janeiro, v. 102, n. 6, p. 671-674, 2007.

MOHAMED, A. H. Subletal toxicity of Roundup to immunological and molecular aspects of Biomphalaria alexandrina to Schistosoma mansoni infection. Ecotoxicology Environmental Safety, New York, v. 74, p. 754-760, 2011.
MONSANTO. Roundup original ${ }^{\circledR}$. 2018. Disponível em: $<$ https:// monsanto.com>.

MONTE, T. C. C.; MALDONADO-JÚNIOR, A. What do we know about the effects of pesticides on helminths? JSM Biology, Jiangsu, v. 2, n. 1, p. 1-6, 2017.

OLIVEIRA-FILHO, E. C.; GRISOLIA, C. K.; PAUMGARTTEN, F. J. R. Effects of endosulfan and ethanol on reproduction of the snail Biomphalaria tenagophila: A multigeration study. Chemosphere, Elmsford, v. 75, p. 398-404, 2009.

PARAENSE, W. L.; CORRÊA, L. R. A potential vector of Schistosoma mansoni in Uruguai. Memórias do Instituto Oswaldo Cruz, Rio de Janeiro, v. 84, n. 3, p. 281-288, 1989.

PERES, F.; MOREIRA, J. C. Saúde e ambiente em sua relação com o consumo de agrotóxicos em um pólo agrícola do Estado do Rio de Janeiro. Cadernos de Saúde Pública, São Paulo, v. 23, Suppl 4, p. 612-621, 2007.

PROSSER, R. S.; GIL-RODRIGUEZ, J. L.; SOLOMON, K. R.; SIBLEY, P. K.; POIRIER, D. G. Effects of the herbicide surfactant mon 0818 on oviposition and viability of eggs of the Ramshorn snail (Planorbella pilsbryi). Environmental Toxicology and Chemistry, Houston, v. 9999, p. 1-10, 2016.

RELYEA, R. A. The impact insecticides and herbicides on the biodiversity and productivity of aquatic communities. Ecological Applications, Ithaca, v. 15, n. 2, p. 618-627, 2005.

RITTSCHOF, D.; MCCLELLAN-GREEN, P. Molluses as multidisciplinary models in environment toxicology. Marine Pollution Bulletin, Amsterdam, v. 50, p. 369-373, 2005.

TOLEDO, R.; FRIED, B. Biomphalaria snails and larval tremadodes. 1 ed. New York: Springer, 2011. 157 p.

VASCONCELLOS, M. C.; AMORIM, A. Molluscicidal action of Euphorbia splendens var. hislopii N.E.B. (Christ!s Crown) (Euphorbiaceae) against Lymnaea columella Say, 1817 (Pulmonata: Lymnaeidae), intermediate host of Fasciola hepatica Linnaeus, 1758 (Trematoda: Fasciolidae). 1: Test in Lab. Memórias do Instituto Oswaldo Cruz, Rio de Janeiro, v. 98, n. 4, p. 557-563, 2003. 